\title{
Fiber Residues from Canavalia ensiformis L. Seeds with Potential Use in Food Industry
}

\author{
Maira Rubi Segura-Campos, Lourdes Manrique-Reynoso, Luis Chel-Guerrero, \\ David Betancur-Ancona* \\ Faculty of Chemical Engineering, Autonomous University of Yucatán, Merida, Mexico \\ Email: ${ }^{*}$ bancona@uady.mx
}

Received 1 September 2014; revised 29 September 2014; accepted 30 October 2014

Copyright (C) 2014 by authors and Scientific Research Publishing Inc.

This work is licensed under the Creative Commons Attribution International License (CC BY). http://creativecommons.org/licenses/by/4.0/

\section{c) (i) Open Access}

\begin{abstract}
The objective of this research was to determine the physicochemical characteristics of fiber residues from Jack bean (Canavalia ensiformis L.) obtained by two technological processes. The proximal composition of the fiber residues from Canavalia ensiformis registered values of moisture, ash, protein, fat, fiber and nitrogen-free extract (NFE) of $7.14 \%, 3.17 \%, 9.14 \%, 1.34 \%$, $23.84 \%$ and $62.51 \%$ for residue $A$ and $4.74 \%, 2.68 \%, 7.73 \%, 1.39 \%, 23.76 \%$ and $64.44 \%$ for residue $B$. Total dietary fiber (TDF) contents in the fiber residues were 47.06 (Residue A) and 54.96 (Residue B) $\mathrm{g} / 100 \mathrm{~g}$ sample, with most of this content represented by insoluble dietary fiber (IDF) $45.46 \mathrm{~g} / 100 \mathrm{~g}$ sample in Residue $A$ and $52.75 \mathrm{~g} / 100 \mathrm{~g}$ of sample in Residue $B$. The remainder was constituted by soluble dietary fiber (SDF). The neutral detergent fiber (NDF) content was slightly higher in residue $B(41.8 \mathrm{~g} / 100 \mathrm{~g}$ sample). Acid detergent fiber (ADF) that includes principally cellulose, lignin and cutin, and acid detergent lignin (ADL) that include lignin and cutin were higher in residue $B(32.5 \mathrm{~g} / 100 \mathrm{~g}$ sample) and similar for both residues $(1.0(\mathrm{~A})$ and $1.2(\mathrm{~B}) \mathrm{g} / 100 \mathrm{~g}$ sample), respectively. Resistant starch (RS) was higher in residue $B(0.607 \%)$ than in residue $A$ $(0.358 \%)$. No statistical difference $(p>0.05)$ was registered in the tannins content of both residues. However, the phytates content was higher in the fiber residue obtained by the fists technological process (A residue). In vitro digestibility was higher in residue A $(85.81 \%)$ than that in $B$ residue $(81.51 \%)$. The results of the present study suggest the potential use of $C$. ensiformis fiber residues as a functional ingredient in foods, especially in the development of reduced calorie food and dietary fiber enriched foods.
\end{abstract}

\section{Keywords}

C. ensiformis, Jack Bean, Dietary Fiber, Chemical Characterization, In Vitro Digestibility

\footnotetext{
${ }^{*}$ Corresponding author.
} 


\section{Introduction}

The genus Canavalia encompasses a group of 48 species distributed throughout the tropics. Jack bean (Canavalia ensiformis L.) is one of the neglected tropical leguminous plants with high productive yield in seeds and foliage [1]. During centuries, the Jack bean legume has been used by local inhabitants of the southwest United States, Central America, Mexico, Brazil, Peru, Equator and the west of India. The great adaptability of C. ensiformis to adverse conditions, mainly soil-related, has been of great relevance for the high protein production in regions inept for agriculture. Besides the seeds being a good source of protein and its use as livestock feed, this plant is also used in soil recovery in several countries [2]. In all legumes, the presence of anti-nutritional components may limit its use as food and feed. In response, wet-fractionation process has been proposed to improve the biological quality of seeds. For Canavalia ensiformis, two technological processes have been reported for integral use of seeds and obtaining protein concentrates, starch and fiber residues. Both methods are based on protein solubility at isoelectric point. In the first process, Canavalia ensiformis flour/water $(1: 7 \mathrm{w} / \mathrm{v})$ dispersion was prepared and $\mathrm{pH}$ was adjusting to 12 and soaking for 12 hours [3]. In second method, flour/water dispersion was 1:6 (w/v), $\mathrm{pH} 11$ and 1 hour of soaking time [4].

The rapidly growing food industry demands new ingredients. This has drawn the attention of researchers to legume components suited for wet-fractionation. At the moment, there is a strong public interest in food ingredients from natural sources. In response, the wet-fractionation process has been proposed as a means of detoxification of Jack beans, but has also been proven as a viable technology for integral use of this seed. Wet-fractionation produces protein concentrates, fiber rich fractions and two starch fractions. For food processing purposes, fiber represents a nutritionally interesting material because of its complexity [5].

Now, when most of the people are getting educated, they remain in regular touch with the information sources like television, print media, periodicals etc. This leads to the generation of awareness and interest among consumers about the nutritional and therapeutic aspects of the food they eat and directing new inquiries about the linkage between food and health. The basic tendency of human beings has always been to procure and consume "natural foods". However, the fast pace of modern life, changes in socioeconomic factors in the recent years, rapid urbanization, industrialization and globalization have kept consumers away from natural foods and, consequently, canned, packaged, and ready-to-eat foods. Most of these foods are rich in fats and sugar, but deficient in complex carbohydrates. Epidemiological research has demonstrated a relationship between this type of diet and the increase of a number of chronic diseases, including colon cancer, obesity, cardiovascular diseases and several other disorders [6]. According to Kritchevsky [7] research findings give enough association between dietary fiber intake and a healthier life style and fiber intake can be regarded as a marker of healthy diet. A generous intake of dietary fiber reduces the risk for developing coronary heart disease, stroke, hypertension, diabetes, obesity and certain gastrointestinal disorders. Furthermore, increased consumption of dietary fiber improves serum lipid concentrations, lowers blood pressure, improves blood glucose control in diabetes, promotes regularity, aids in weight loss and appears to improve immune function [8].

Given the demand of the food industry for new functional ingredients, it is worthwhile to characterize the Canavalia ensiformis fiber with a view toward establishing its possible uses and adding values to this legume seed. For the above mentioned, the objective of this research was to determine the chemical components of fiber residues of Canavalia ensiformis by two technological processes.

\section{Materials and Methods}

\subsection{Materials}

C. ensiformis seeds were obtained in the state of Yucatan, Mexico. Impurities and damaged seeds were removed. Sound seeds were milled in a Mykros impact mill until passing through a 20-mesh screen $(0.85 \mathrm{~mm})$. Reagents were analytical grade and purchased from J. T. Baker (Phillipsburg, NJ, USA), Sigma Chemical Co. (St. Louis, MO, USA), Merck (Darmstadt, Germany) and Bio-Rad Laboratories, Inc. (Hercules, CA, USA).

\subsection{Fiber Residues}

Two technological processes were used to obtain the fiber residues. In the first process (residue A), C. ensiformis flour was suspended in distilled water at a $1: 7(\mathrm{w} / \mathrm{v})$ ratio, the $\mathrm{pH}$ was adjusted to 12 with $1 \mathrm{~mol} / \mathrm{L} \mathrm{NaOH}$ and it was allowed to stand for $12 \mathrm{~h}$ [3]. This suspension was wet-milled with a Kitchen-Aid ${ }^{\circledR}$ mill and the fiber 
solids separated from the starch and protein mix by straining through 80-mesh sieves followed by five washings of the residue with distilled water. The fiber residue was milled through 80- and 150-mesh sieves, oven-drying at $50^{\circ} \mathrm{C}$ for overnight and then milled in a Mykros impact mill until passing through a 20-mesh screen $(0.85$ $\mathrm{mm})$. In the second process (Residue B), whole flour was suspended in distilled water at a 1:6 (w/v) ratio, $\mathrm{pH}$ adjusted to 11 with $1 \mathrm{~mol} / \mathrm{L} \mathrm{NaOH}$, and the dispersion stirred for $1 \mathrm{~h}$ at $400 \mathrm{rpm}$ with a mechanical agitator (Caframo Rz-1, Heidolph Schwabach, Germany) [4]. This suspension was wet-milled with a Kitchen-Aid ${ }^{\circledR}$ mill and the fiber solids separated from the starch and protein mix by straining through 80- and 150-mesh sieves followed by five washings of the residue with distilled water. The fiber residue was oven drying at $50^{\circ} \mathrm{C}$ for overnight and then milled in a Mykros impact mill until passing through a 20-mesh screen $(0.85 \mathrm{~mm})$.

\subsection{Proximal Composition of $C$. ensiformis Fiber Residues}

Standard AOAC [9] procedures were used to determine nitrogen (method 954.01), fat (method 920.39), ash (method 925.09), crude fiber (method 962.09), and moisture (method 925.09) contents in the C. ensiformis fiber residues. Nitrogen $\left(\mathrm{N}_{2}\right)$ content was quantified with a Kjeltec Digestion System (Tecator, Höganäs, Skåne län, Sweden) using cupric sulfate and potassium sulfate as catalysts. Protein content was calculated as nitrogen $\times$ 6.25. Fat content was obtained from a $1 \mathrm{~h}$ hexane extraction. Ash content was calculated from sample weight after burning at $550^{\circ} \mathrm{C}$ for $2 \mathrm{~h}$. Moisture content was measured based on sample weight loss after oven-drying at $110^{\circ} \mathrm{C}$ for $2 \mathrm{~h}$. Carbohydrate content was estimated as nitrogen-free extract (NFE) by difference from the sum of the protein, fat, ash and crude fiber content.

\subsection{Total Dietary Fiber (TDF)}

This parameter was determined with the gravimetric enzymatic method proposed by Prosky et al. [10]. Briefly, $1 \mathrm{~g}$ of sample was weighed into each of four flasks and $50 \mathrm{~mL}$ of phosphate buffer $(50.0 \mathrm{mM}, \mathrm{pH}$ ) were added to each. The flasks were then placed in a water bath at $100^{\circ} \mathrm{C}, 0.1 \mathrm{~mL}$ of thermostable $\alpha$-amylase enzyme (Sigma A-3306) was added to each and then they were agitated at $60 \mathrm{rpm}$ for $15 \mathrm{~min}$. After cooling, $\mathrm{pH}$ was adjusted to 7.5. The flasks were returned to the bath at $60^{\circ} \mathrm{C}, 0.1 \mathrm{~mL}$ protease (Sigma P-3910) added to each and then they were agitated at $60 \mathrm{rpm}$ for $30 \mathrm{~min}$. After cooling, $\mathrm{pH}$ was adjusted to 4.0. The flasks were again placed in the bath at $60^{\circ} \mathrm{C}, 0.3 \mathrm{~mL}$ amyloglucosidase (Sigma A-9913) added and then they were agitated for $30 \mathrm{~min}$. Finally, ethanol $95 \%(\mathrm{v} / \mathrm{v})$, preheated to $60^{\circ} \mathrm{C}$, was added at a 1:4 (v/v) ratio. In a vacuum, flask content was filtered into crucibles containing celite (Sigma C-8656). The residue remaining in the flask was washed three times with 20 $\mathrm{mL}$ of ethanol $78 \%(\mathrm{v} / \mathrm{v})$, twice with $10 \mathrm{~mL}$ of ethanol $95 \%(\mathrm{v} / \mathrm{v})$ and twice with $10 \mathrm{~mL}$ acetone. Crucible content was dried at $105^{\circ} \mathrm{C}$. Protein $(\mathrm{N} \times 6.25)$ was determined for the residue in two crucibles and the residue in the remaining two was burned at $550^{\circ} \mathrm{C}$ for $4 \mathrm{~h}$.

$$
\operatorname{TDF}(\%)=\frac{[\text { Residue weight }(\mathrm{g})-\text { protein }(\mathrm{g})-\text { ash }(\mathrm{g})] \times 1000}{\text { Sample weight }(\mathrm{g})}
$$

\subsection{Insoluble Dietary Fiber (IDF)}

This was determined following the method of Prosky et al. [10], which is similar to that for TDF, except that addition of ethanol $95 \%(\mathrm{v} / \mathrm{v})$ at 1:4 (v/v) is omitted.

Soluble Dietary Fiber (SDF)

Calculated by the difference between TDF and IDF:

$$
\mathrm{SDF}=\mathrm{TDF}-\mathrm{IDF} .
$$

\subsection{Van Soest Fiber Components}

\subsubsection{Acid Detergent Fiber (ADF)}

Samples were oven dried at $55^{\circ} \mathrm{C}$ to dry matter, then ground to pass a $1 \mathrm{~mm}$ screen. Dry $50 \mathrm{~mL}$ fritted glass crucibles overnight at $100^{\circ} \mathrm{C}$ and hot weigh (W1), recording weight to nearest $0.1 \mathrm{mg}$. Thoroughly sample was weighted (W2) (approximately 0.9 to $1.1 \mathrm{~g}$, record weight accurate to $0.1 \mathrm{mg}$ ) into Berzelius beaker. A volume 
of $100 \mathrm{~mL}$ acid-detergent solution (20 g of Cetyltrimethylammonium bromide (CTAB) technical grade in $1 \mathrm{~L}$ of sulfuric acid $1.0 \mathrm{~N}$ ) was added at room temperature. Sample was heat to boiling in 5 - $10 \mathrm{~min}$; heat was reduced to avoid foaming as boiling begins. The sample was refluxed $60 \mathrm{~min}$ from onset of boil, adjusting boiling to slow, even level. After approximately $30 \mathrm{~min}$, washing the beakers using minimal amount of acid detergent solution. The sample was filtered through tared fritted glass crucible, using minimal vacuum. The Berzelius beaker was washing with boiling water while inverted over the crucible to insure quantitative transfer of all fiber particles into the crucible. The residue was rinse twice with $30-40 \mathrm{~mL}$ acetone by filling crucible each time with vacuum off, allowing a minimum of 15 to $30 \mathrm{sec}$ ( 2 min recommended) before vacuuming dry. Finally the residue was dried overnight in forced-air oven at $100^{\circ} \mathrm{C}$ and weigh hot, recording weight (W3) to nearest $0.1 \mathrm{mg}$. Percent acid detergent fiber (ADF) was calculated as follows [11]:

$$
\% \operatorname{ADF}(\mathrm{DM} \text { basis })=(\mathrm{W} 3-\mathrm{W} 1 / \mathrm{W} 2) \times 100
$$

where:

$\mathrm{W} 1$ = Tare weight of crucible in grams;

W2 = Initial sample weight in grams;

W3 = Dry weight of crucible and dry fiber in grams.

\subsubsection{Neutral Detergent Fiber (NDF)}

Samples were processed similar than method reported for ADF using a volume of $100 \mathrm{~mL}$ neutral-detergent solution. The solution was prepared with distilled water, sodium borate, EDTA, lauryl sulfate, 2-ethoxyethanol and disodium phosphate. The $\mathrm{pH}$ was adjusted at 6.9 - 7.1 [11].

\subsubsection{Acid Detergent Lignin (ADL)}

Samples were processed similar than method reported for ADF using a volume of $100 \mathrm{~mL} 72 \% \mathrm{H}_{2} \mathrm{SO}_{4}$ solution. The crucible with sample was ignited in a muffle furnace at $500^{\circ} \mathrm{C}$ for 2 hours. The crucible was weighted to the nearest $0.1 \mathrm{mg}$ (W3) [12].

\subsubsection{Cellulose and Hemicellulose}

These parameters were calculated as follows:

$\%$ Cellulose = ADF (Cellulose, lignin, cutin) - ADL (Lignin, cutin).

$\%$ Hemicellulose $=$ NDF (Hemicellulose, cellulose, lignin, cutin) - ADF (Cellulose, lignin, cutin).

\subsection{Resistant Starch (RS)}

RS was measured using the modified method suggested by Saura-Calixto et al. [13]. The method uses the principle of determining RS from the insoluble dietary fiber. It consists of the enzymatic hydrolysis of starch with heat stable $\alpha$-amylase (Sigma No. A-3306) followed by a proteolyticdegradation with a protease (Sigma No. P3310). Subsequently the starch hydrolysis was realized with an amyloglucosidase (Sigma A-9913) to yield glucose. The insoluble dietary fiber was obtained after several steps of rinsing and centrifugation. The RS was extracted from the insoluble residue with $4 \mathrm{MKOH}$ and retreated with amyloglucosidase (Boehringer Mannheim No. 102857). Glucose was determined in the supernatant with the reagent GOD-POD (glucose oxidase/peroxidase). RS was calculated as glucose $(\mathrm{mg}) \times 0.9$ (conversion factor due to starch hydrolysis).

\subsection{Tannins Content}

The tannin content of the samples was determined using the International Standardization Organization method [14]. This method consist in extraction by shaking with dimethylformamide, then after centrifuging, addition of ferric ammonium citrate and ammonia to an aliquot part of the supernatant liquid and spectrometric determination, at $525 \mathrm{~nm}$, of the absorbance of the solution thus obtained, and determine of the tannic content using a calibration curve prepared using tannic acid.

\subsection{Phytates Content}

Phytates were determined by the Anion-Exchange method as described by AOAC [15] method number 986.11. 
Phosphate was used as a standard. Samples were weighed (2 g) and transferred to Erlenmeyer flasks to which $2.4 \% \mathrm{HCl}(40 \mathrm{~mL})$ was added. The mixture was homogenized for 3 hours. Columns were prepared by adding resin $(0.5 \mathrm{~g})$ into the columns. After forming, resin beds were washed with $0.7 \mathrm{M} \mathrm{NaCl}$ and distilled water. Homogenized samples were filtered and the filtrate $(2 \mathrm{~mL})$ transferred to $25 \mathrm{ml}$ volumetric flasks. The $\mathrm{Na}_{2} \mathrm{EDTA}-$ $\mathrm{NaOH}$ reagent $(2 \mathrm{~mL})$ was added and the solution diluted to volume with water. The solution was mixed and transferred to the column and the eluate then discarded. Water $(15 \mathrm{~mL})$ and $0.1 \mathrm{M} \mathrm{NaCl}(15 \mathrm{~mL})$ were eluted through column and eluate discarded. A $0.7 \mathrm{M} \mathrm{NaCl}(15 \mathrm{~mL})$ was eluted through the column and eluate collected in digestion flasks. Concentrated $\mathrm{H}_{2} \mathrm{SO}_{4}$ acid $(1 \mathrm{~mL})$ and $\mathrm{HNO}_{3}$ acid $(6 \mathrm{~mL})$ were added to the flasks, and digested until active boiling ceased. After cooling, water $(10 \mathrm{~mL})$ was added; flasks swirled and heated at low temperature for $10 \mathrm{~min}$ to dissolve the salt. The cooled solution was transferred to a volumetric flask (50 mL); molybdate solution $(4 \mathrm{~mL})$ and sulfonic acid $(2 \mathrm{~mL})$ were added. The solution was diluted to volume with water and left to stand for $15 \mathrm{~min}$. Absorbance was read at $640 \mathrm{~nm}$ using atomic absorption spectrophotometer.

\subsection{In Vitro Digestibility}

The reference method used was that proposed by Tilley and Terry [16]. Briefly, $0.25 \mathrm{~g}$ of sample was weighed in triplicate and incubated for $48 \mathrm{~h}$ with a mixture of Mc Dougall (1948) buffer solution and inoculated with rumen fluid and the mixture was saturated with $\mathrm{CO}_{2}$. This was followed by an incubation period of $48 \mathrm{~h}$ with 25 $\mathrm{mL}$ of a solution of acid pepsin. The residue obtained after filtration with filter paper was dried at $105^{\circ} \mathrm{C}$. This method was employed with rumen liquors obtained from rumen fistulated calves that were fed ad libitum with alfalfa and pasture.

\subsection{Statistical Analysis}

All results were analyzed using descriptive statistics with a central tendency and dispersion measures. One-way ANOVAs were run to evaluate proximate composition, dietary fiber content and functional properties. All analyses were done according to Montgomery [17] and processed with the Statgraphics Plus version 5.1 software.

\section{Results and Discussion}

\subsection{Proximal Composition}

The proximal composition of the fiber residues from Canavalia ensiformis registered values of moisture, ash, protein, fat, fiber and NFE of 7.14\% \pm 0.289\%, 3.17\% $\pm 0.090 \%, 9.14 \% \pm 0.015 \%, 1.34 \% \pm 0.017 \%, 23.84 \% \pm$ $0.277 \%$ and $62.51 \% \pm 0.226 \%$ for residue $\mathrm{A}$ and of $4.74 \% \pm 0.108 \%, 2.68 \% \pm 0.026 \%, 7.73 \% \pm 0.076 \%, 1.39 \%$ $\pm 0.023 \%, 23.76 \% \pm 0.490 \%$ and $64.44 \% \pm 0.488 \%$ for residue B (Table 1 ). The low fat content of both fiber residues suggests that could be used like food for communities that requires low fat diets. The crude fiber content was similar for $C$. ensiformis fiber residues obtained for different technological process and had high amounts of crude fiber and carbohydrates. Fiber has a useful role in providing roughed that aids digestion and carbohydrates contributes to fat metabolism and spare proteins as energy source for human beings. Considering the primary nutrient composition of the $C$. ensiformis fiber residues, these could be used as functional foods.

Table 1. Proximal composition of fiber residues (A and B) from Canavalia ensiformis (\% d.b.).

\begin{tabular}{ccc}
\hline & \multicolumn{2}{c}{ Residue } \\
\cline { 2 - 3 } Component & A & B \\
\hline Moisture & $(7.14 \pm 0.289)^{\mathrm{a}}$ & $(4.74 \pm 0.108)^{\mathrm{b}}$ \\
Ash & $3.17 \pm 0.090^{\mathrm{a}}$ & $2.68 \pm 0.026^{\mathrm{b}}$ \\
Protein & $9.14 \pm 0.015^{\mathrm{a}}$ & $7.73 \pm 0.076^{\mathrm{b}}$ \\
Fat & $1.34 \pm 0.017^{\mathrm{b}}$ & $1.39 \pm 0.023^{\mathrm{a}}$ \\
Crude fiber & $23.84 \pm 0.277^{\mathrm{a}}$ & $23.76 \pm 0.490^{\mathrm{a}}$ \\
\hline Nitrogen-free extract (NFE) & $62.51 \pm 0.226^{\mathrm{b}}$ & $64.44 \pm 0.488^{\mathrm{a}}$ \\
\hline
\end{tabular}

${ }^{a-b}$ Different superscript letters in the same row indicate statistical difference $(\mathrm{p}<0.05)$. 


\subsection{Total, Soluble and Insoluble Dietary Fiber}

According to Verma and Banerjee [8] the term dietary fiber was used first by Hipsley [18] to include lignin, cellulose and hemicellulose, and later broadened to include soluble substances (non-cell-wall derived materials) such as pectins, gums and mucilages. This broad definition acknowledges the significance of fiber as a chemical and physiological component of the diet as compared with the static definition of crude fiber-"the residue of plant food left after extraction with solvent, dilute acid, and dilute alkali”. Trowell et al. [19] adopted Hipsley's term in conjunction with a number of health-related hypotheses they were developing, referred to as their "dietary fiber hypotheses". The term was used to describe the remnants of plant components that are resistant to hydrolysis by human alimentary enzymes. Thus it was a physiological-botanical description, characterizing dietary fiber's indigestibility in the human small intestine, with plant cell walls being the major source of digestion-resistant material. The components included were cellulose, hemicellulose, lignin, and associated minor substances, such as waxes, cutin, and suberin. One widely accepted definition from the American Association of Cereal Chemists states: "Dietary fiber is the remnants of the edible parts of plants or analogous carbohydrates that are resistant to digestion and absorption in the human small intestine with complete or partial fermentation in the large intestine. According to this definition dietary fiber includes polysaccharides, oligosaccharides, lignin, and associated plant substances. Dietary fibers promote beneficial physiological effects including laxation, and/or blood cholesterol attenuation, and/or blood glucose attenuation” [20]. These are an integral part of the foodstuffs we consume daily plants, vegetables, cereal grains, woody plants, fruits, legumes, leguminous plants, etc. [21]. The latest definition proposed by Codex Alimentarius includes carbohydrate polymers with a degree of polymerization not lower than 3 . They can be naturally present in or extracted from food raw material, or synthesized. The debate continues and some recent opinion has favored a return to the original fiber definition along the lines that "Dietary fiber consists of intrinsic plant cell wall polysaccharides" [8].

Based on their simulated intestinal solubility, dietary fiber is conventionally classified into two categories: soluble dietary fiber such as pentosans, pectin, gums, and mucilage and insoluble dietary fiber such as cellulose, part of hemicellulose, and lignin [8]. TDF content in the C. ensiformis fiber residues were 47.06 (Residue A) and 54.96 (Residue B) g/100g sample, with most of this content represented by IDF $45.46 \mathrm{~g} / 100 \mathrm{~g}$ sample in Residue A and $52.75 \mathrm{~g} / 100 \mathrm{~g}$ of sample in residue B. The remainder was constituted by SDF (Figure 1 ). The soluble or easily digestible fibers of $C$. ensiformis could increase transit time through the digestive tract, delay gastric emptying, and slow glucose absorption so that the amount of starch reaching the colon is increased. The C. ensiformis insoluble fiber, on the other hand, could increase fecal bulk and excretion of bile acids, while decreasing intestinal transit time.

\subsection{Van Soest Fiber Components}

Neutral detergent fiber and acid detergent fiber are widely used analytical methods for the estimation of the nutritive qualities of feed. They were originally proposed by Van Soest [22], but have undergone significant

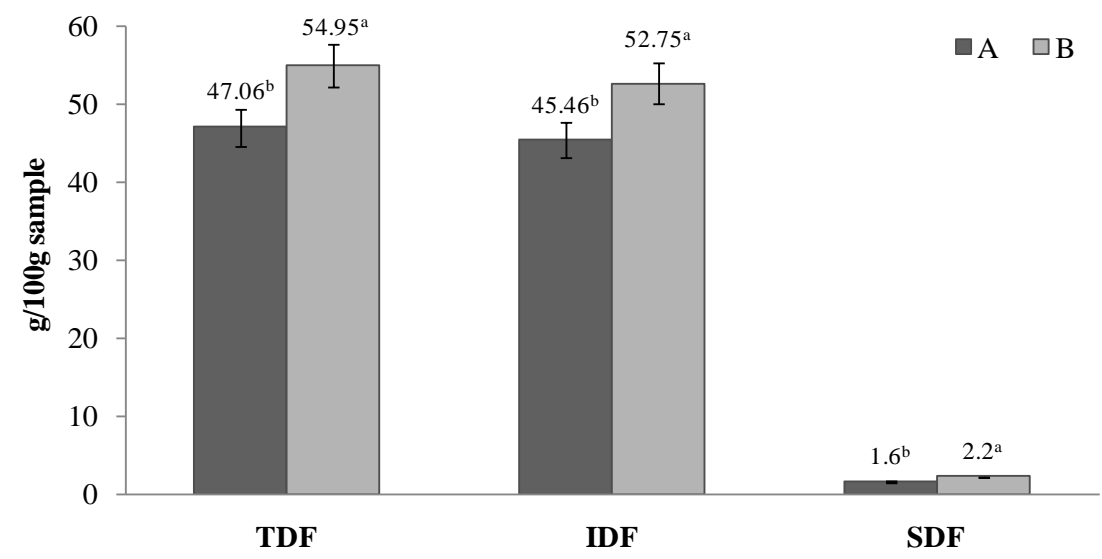

Figure 1. Total (TDF), soluble (SDF) and insoluble dietary fiber (IDF) of fiber residues (A and B) from Canavalia ensiformis. ${ }^{a-b}$ Different superscript letters in the same component indicate statistical difference $(\mathrm{p}<0.05)$. 
changes over the years [11]. Van Soest's fractionation makes it possible to measure the total cell wall content (NDF), lignocellulose content (ADF) and lignin content (ADL). Figure 2 shows NDF, ADF and ADL content of fiber residues from C. ensiformis. NDF includes mainly insoluble hemicellulose, cellulose, lignin and cutin. The NDF content was slightly higher in residue B. ADF that include principally cellulose, lignin and cutin, and ADL that include lignin and cutin were higher in residue B and similar for both residues, respectively. The Van Soest components from $C$. ensiformis fiber residues could play significant roles towards various physicochemical characteristics of foods besides improvement of various physiological and health values. These functions are contributed by different interlinked inherent attributes of fiber such as solubility, water and fat binding capacity as well as viscosity. Such properties of dietary fiber make them a vital ingredient while design and development of different products.

Figure 3 shows the hemicellulose and cellulose contents of $C$. ensiformis fiber residues. Hemicellulose content was higher in residue A and cellulose content in residue B. Hemicellulose content was estimated by difference between NDF and ADF. Cellulose content was estimated by difference between ADF and ADL. Cellulose and hemicellulose are components of insoluble dietary fiber. Insoluble fiber increasedfecal bulk, excretion of bile acids and while decreasing intestinal transit time. For the above mentioned, the cellulose and hemicellulose contained in C. ensiformis fiber residues may be due an alternative in the prevention and management of chronic diseases.

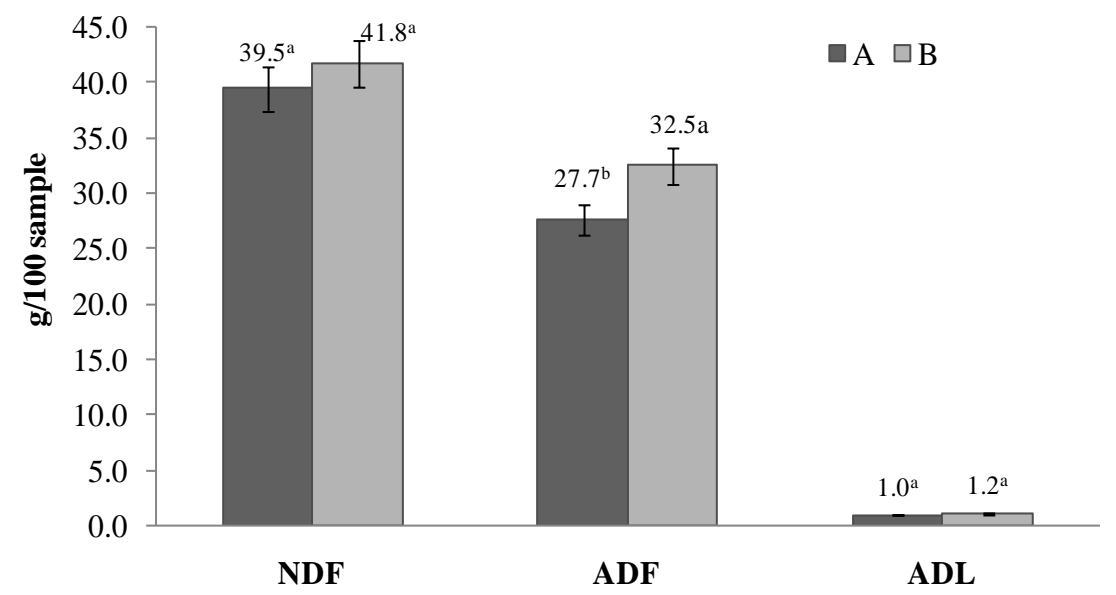

Figure 2. Neutral detergent fiber (NDF), acid detergent fiber (ADF) and acid detergent lignin (ADL) of fiber residues (A and B) from Canavalia ensiformis. ${ }^{a-b}$ Different superscript letters in the same component indicate statistical difference $(p<0.05)$.

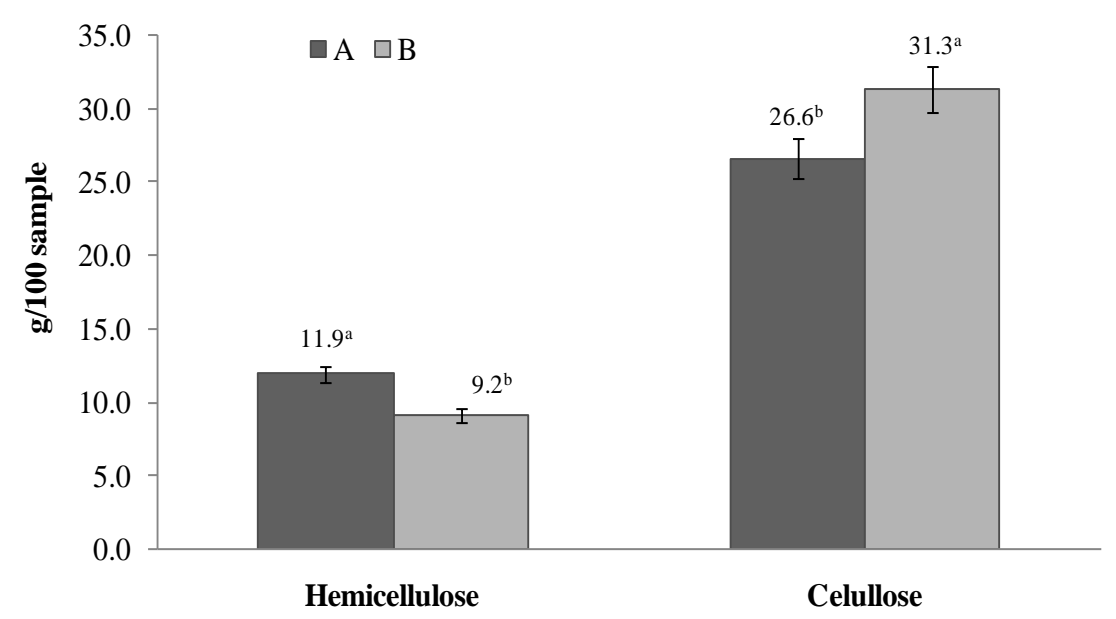

Figure 3. Hemicellulose and cellulose content of fiber residues (A and B) from Canavalia ensiformis. ${ }^{\mathrm{a}-\mathrm{b}}$ Different superscript letters in the same component indicate statistical difference $(\mathrm{p}<0.05)$. 


\subsection{Resistant Starch (RS)}

Starch has always been considered fully digestible, but it has been found that, for various reasons (biological origin by technological processes and/or food preparation) some of the starch remaining in the residue is not digestible by enzymes in the intestine thin, i.e. it passes into the colon along with the polysaccharide to form the fiber. Therefore, the concept changed this nutrient that is believed fully digestible, a fact confirmed in vivo when tested in ileostomised patients [23]. The RS level found in C. ensiformis fiber residues was higher in residue B $(0.607 \%)$ than residue A $(0.358 \%)$. According to Zulueta [23] the digestion rate of the starch is affected by the inherent and acquired through food. The physical matrix is highlighted, which influences the accessibility of digestive enzymes. This rigid matrix is relevant in the amylose content, which in the majority of starches reaches about $25 \%$. Another factor is the ratio of amylose and amylopectin starch: the amylose molecule is mainly linear, which is stiffer and less sensitive to the action of amylase, whereas amylopectin is a branched structure that facilitates the enzymatic action. Although the C. ensiformis fiber residues registered low levels of RS, this can contribute with the physiological properties of dietary fiber.

\subsection{Tannins and Phytates}

Figure 4 shows the tannins and phytates content of $C$. ensiformis fiber residues. No statistical difference was registered in the tannins content of both fiber residues ( $p>0.05$ ). However, the phytates content was higher in the fiber residue obtained with the first technological process (residue A). The low tannins and phytates levels registered here could be due to the technological processes employed during the fiber residues extraction. At this respect, Bressani [24] establish that processing practices as soaking at alkaline $\mathrm{pH}$, extruded, germ and frying reduce the tannin and phytates content. Also, the low-phytate content could be because these components are found in higher proportion in cotyledons and poorly in pericarp.

According to Goñi [25], vitamins, carotenoids and phenolic compounds such as tannins are recognized as the main groups of antioxidants present in plant foods. Dietary fiber and antioxidants are healthy food constituents and functional ingredients that are generally addressed separately in both chemical and nutritional studies. However, it has been proven that a substantial proportion of the antioxidant polyphenols [26] and carotenoids [27] contained in plant foods are linked to dietary fiber, and that they are a substantial part of the total antioxidants in the diet. It therefore seems logical to suppose that the association between antioxidants and dietary compounds such as tannins present in C. ensiformis may contribute significantly to the health effects, and that some of the postulated benefits of the fiber intake can be attributed to the dietary fiber-antioxidants complex. This capacity of the fiber matrix to act as a carrier of antioxidant compounds is an essential physiological function of dietary fiber. The release of some antioxidant compounds in the colon improves antioxidant status and

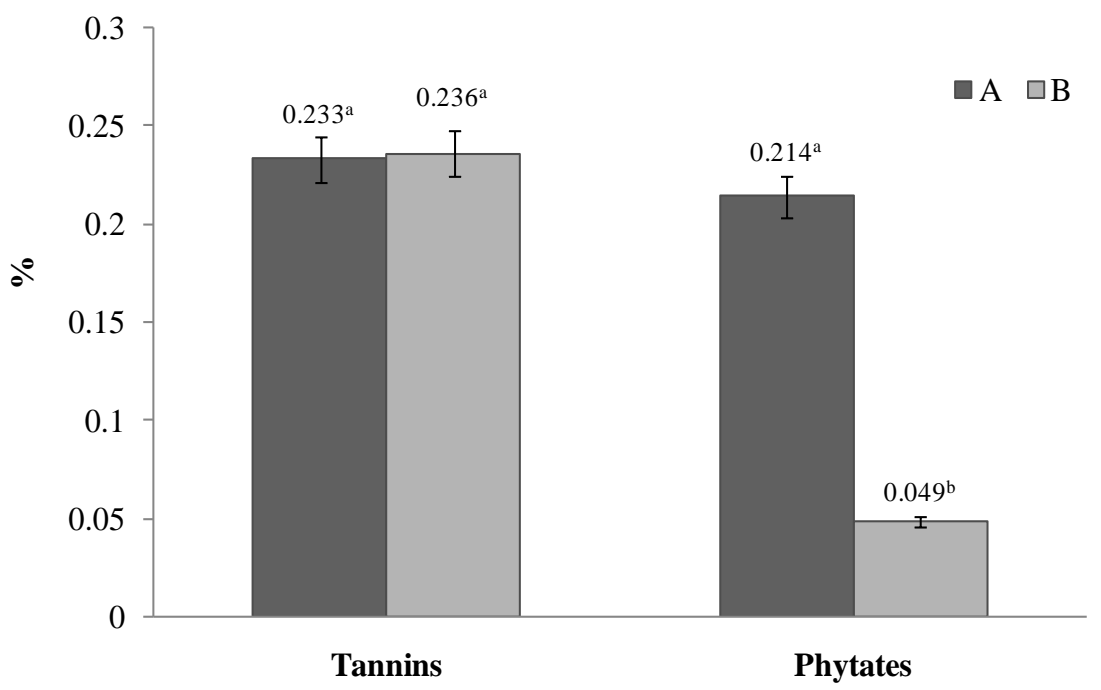

Figure 4. Tannins and phytates content of fiber residues (A and B) from Canavalia ensiformis. ${ }^{\mathrm{a}-\mathrm{b}}$ Different superscript letters in the same component indicate statistical difference $(p<0.05)$. 
yields different metabolites with potential systemic effects [25]. Therefore, C. ensiformis dietary fiber or its constituents such as tannins, and antioxidants could be approached jointly in nutrition and health studies, combining the properties of both dietary fiber and antioxidants in a single material.

\subsection{In Vitro Digestibility}

Tilley and Terry [16] method is a biological method in which, under conditions which simulate those within the rumen of a sheep (anaerobic, near neutral $\mathrm{pH}$, blood heat), small samples of fiber residues can be digested with crude rumen liquor rich in microorganisms. In vitro digestibility was higher in residue A (85.81\%) than that residue B (81.51\%). The high levels of digestibility registered here could be due to the low lignin contents as well as to the high NFE, which is the digestible portion by microbial enzymes.

\section{Conclusion}

The results suggest that both Canavalia ensiformis fiber residues are a good source of dietary fiber. Comparatively, the residue B obtained with the technological process with the conditions flour/water ratio (1: $6 \mathrm{w} / \mathrm{v}), \mathrm{pH}$ 11 and 1 hour of soaking time, was better because it had a higher content of total dietary fiber (TDF), dietary fiber soluble (IDF), acid detergent fiber (ADF), neutral detergent fiber (NDF) and resistant starch (RS). The shorter process (1 hour) represents a technological advantage over the process A (12 hours). Dietary fiber intake provides many health benefits. A generous intake of dietary fiber reduces risk for developing the diseases as coronary heart disease, stroke, hypertension, diabetes, obesity and certain gastrointestinal disorders. Furthermore, increasing consumption of dietary fiber improves serum lipid concentrations, lowers blood pressure, improves blood glucose control in diabetes, promotes regularity, aids in weight loss and appears to improve immune function. The potential physiological effects of $C$. ensiformis fiber residues are related with their physicochemical and functional properties. However, further research is necessary to prove the relationship from C. ensiformis fiber with the health.

\section{References}

[1] Sowndhararajan, K., Siddhuraju, P. and Manian, S. (2011) Antioxidant Activity of the Differentiallly Processed Sedes of Jack Vean (Canavalia ensiformis L. DC). Food Science and Biotecnology, 20, 585-591. http://dx.doi.org/10.1007/s10068-011-0083-9

[2] Zanella, F., Watanabe, T.M., da Silva Lima, A.L. and Schiavinato, M.A. (2004) Photosyntetic Performance in Jack Bean (Canavalia ensiformis L. DC) under Drought and after Rehydratation. Brazilian Journal of Plant and Physiology, 16, 181-184. http://dx.doi.org/10.1590/S1677-04202004000300008

[3] Moguel-Ordoñez, Y., Betancur-Ancona, D. and Chel-Guerrero, L. (1996) Aprovechamiento integral del grano de Canavalia ensiformis: Extracción de proteína y almidón. Tecnología de Alimentos (México), 31, 11-15.

[4] Chel-Guerrero, L., Pérez-Flores, V., Betancur-Ancona, D. and Dávila-Ortiz, G. (2002) Functional Properties of Flours and Protein Isolates from Phaseolus lunatus and Canavalia ensiformis Seeds. Journal of Agriculture and Food Chemistry, 50, 584-591. http://dx.doi.org/10.1021/jf010778j

[5] Novelo-Cen, L. and Betancur-Ancona, D. (2003) Canavalia ensiformis Tailing Starch: A Functional Source of Dietary Fiber. Starch/Starke, 55, 30-37. http://dx.doi.org/10.1002/star.200390003

[6] WHO/FAO (2003) Diet Nutrition and the Prevention of Chronic Diseases. Report of the Joint WHO/FAO Experts Consultation. WHO Technical Report Series, $n^{\circ} 916$.

[7] Kritchevsky, D. (2000) Dietary Fiber in Health and Disease. In: McCleary, B.V. and Prosky, L., Eds., Proceedings of the 1st International Conference on Dietary Fiber, Dublin, Ireland, Blackwell Science, Oxford, 38-40.

[8] Verma, A.K. and Banerjee, R. (2013) Dietary Fiber in Meat Products: Functional and Bioactive Ingredient. In: Ancaona, D.B., Guerrero, L.C. and Campos, M.R.S., Eds., Dietary Fiber: Sources, Properties and Their Relationship to Health, Nova Science Publisher, New York, 63-84.

[9] AOAC (1997) Official Methods of Analysis. 20th Edition, Association of Official Analytical Chemists, Washington, DC.

[10] Prosky, L., Asp, N., Schweizer, T., Devries, S. and Furda, I. (1988) Determination of Insoluble, Soluble and Total Dietary Fiber in Food and Food Products: Interlaboratory Study. Journal of the Association of Official Analytical Chemists, 71, 1017-1023.

[11] Van Soest, P.J., Robertson, J.B. and Lewis, B.A. (1991) Methods for Dietary Fiber, Neutral Detergent Fiber, and Non- 
starch Polysaccharides in Relation to Animal Nutrition. Journal of Dairy Science, 74, 3583-3597. http://dx.doi.org/10.3168/jds.S0022-0302(91)78551-2

[12] AOAC (1990) Fiber (Acid Detergent) and Lignin in Animal Feed. (973.18). 15th Edition, Association of Official Analytical Chemists. Washington DC.

[13] Saura-Cálixto, F., Goñi, I., Bravo, L. and Mañas, E. (1993) Resistantstarch in Foods: Modified Method for Dietary Fiber Residues. Journal of Food Science, 58, 642-643. http://dx.doi.org/10.1111/j.1365-2621.1993.tb04346.x

[14] ISO 9648 (1988) Determination of Tannin Content.

[15] AOAC (2000) Official Methods of Analysis. 20th Edition, Association of Official Analytical Chemists, Washington DC.

[16] Tilley, J.M. and Terry, R.A. (1963) A Two Stage Technique for the in Vitro Digestion of Forage Crops. Journal Association of Agricultural Chemistry, 30, 825-831.

[17] Montgomery, D. (2004) Diseño y análisis de experimentos. Limusa-Wiley, México, D.F.

[18] Hipsley, E.H. (1953) Dietary Fiber and Pregnancy Toxaemia. British Medical Journal, 2, 420-422. http://dx.doi.org/10.1136/bmj.2.4833.420

[19] Trowell, H.C., Southgate, D.A.T., Wolever, T.M.S., Leeds, A.R., Gassull, M.A. and Jenkins, D.J.A. (1976) Dietary Fiber Redefined. The Lancet, 307, 967. http://dx.doi.org/10.1016/S0140-6736(76)92750-1

[20] American Association of Cereal Chemists (AAC) (2001) The Definition of Dietary Fiber. Report of the Dietary Fiber Definition Committee to the Board of Directors of the AAC, 46, 112-126.

[21] Meyer, P.D. (2004) Non-Digestible Oligosaccharides as Dietary Fiber. Journal of the Association of Official Analytical Chemists International, 87, 718-726.

[22] Van Soest, P.J. and Wine, R.H. (1968) The Determination of Lignin and Cellulose in Acid Detergent Fiber with Permanganate. Journal of Association of Official Analytical Chemists, 51, 780-785.

[23] Zuleta, A. (2013) Dietary fiber: From Concept to Realization. In: Ancaona, D.B., Guerrero, L.C. and Campos, M.R.S., Eds., Dietary Fiber: Sources, Properties and Their Relationship to Health, Nova Science Publisher, New York, 189210.

[24] Bressani, R. (1991) Papel de los Granos Leguminosos Comestibles Tropicales en los Alimentos y la Nutrición. En: Por Vargaz, R.E., León, A. y Escobar, A., Edit., Canavalia ensiformis (L.) DC. Producción, procesamiento y utilización en alimentación animal. Memorias del $1^{\text {er }}$ Seminario-Taller sobre Canavalia ensiformis, Maracay, Venezuela, 21-38.

[25] Goñi, I. (2013) Antioxidant Dietary Fiber: Sources and Applications. In: Ancona, D.B., Guerrero, L.C. and Campos, M.R.S., Eds., Dietary Fiber: Sources, Properties and Their Relationship to Health, Nova Science Publisher, New York, 85-108.

[26] Saura-Calixto, F., Serrano, J. and Goñi, I. (2007) Intake and Bioaccessibility of Total Polyphenols in a Whole Diet. Food Chemistry, 101, 492-501. http://dx.doi.org/10.1016/j.foodchem.2006.02.006

[27] Goñi, I., Serrano, J. and Saura-Calixto, F. (2006) Bioaccessibility of Beta-Carotene, Lutein, and Lycopene from Fruits and Vegetables. Journal of Agriculture and Food Chemistry, 54, 5382-5387. http://dx.doi.org/10.1021/jf0609835 
Scientific Research Publishing (SCIRP) is one of the largest Open Access journal publishers. It is currently publishing more than 200 open access, online, peer-reviewed journals covering a wide range of academic disciplines. SCIRP serves the worldwide academic communities and contributes to the progress and application of science with its publication.

Other selected journals from SCIRP are listed as below. Submit your manuscript to us via either submit@scirp.org or Online Submission Portal.
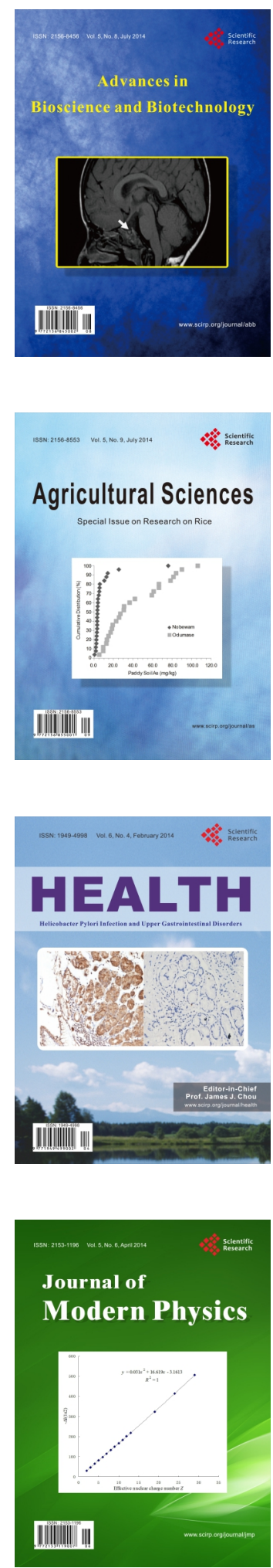
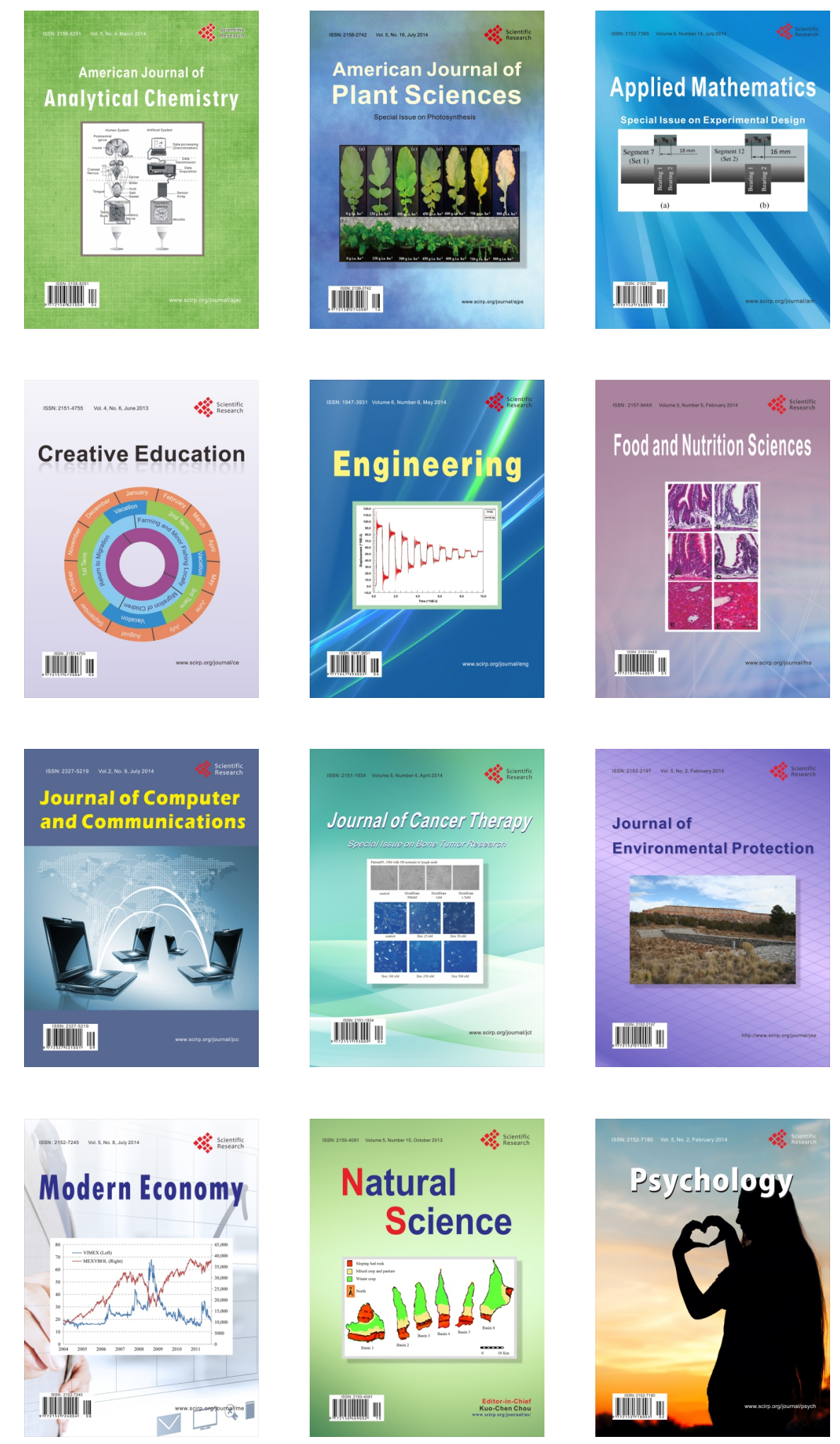